Research article

\title{
PLASMA TOTAL ANTIOXIDANT CAPACITY AND ACTIVITIES OF BLOOD GLUTATHIONE PEROXIDASE AND SUPEROXIDE DISMUTASE DETERMINED IN HEALTHY DOGS BY USING COMMERCIALLY AVAILABLE KITS
}

\author{
TOMSIČ Katerina, SELIŠKAR Alenka, LUKANC Barbara, NEMEC SVETE \\ Alenka*
}

Small Animal Clinic, Veterinary Faculty, University of Ljubljana, Gerbičeva 60, Ljubljana, Slovenia

(Received 16 May; Accepted 22 September 2016)

\begin{abstract}
Data on the values of selected blood antioxidant parameters, i.e. total antioxidant capacity, glutathione peroxidase, and superoxide dismutase in healthy dogs, are lacking. There are no published accepted standard reference methods for their determination. The aim of this study was to determine the values of plasma total antioxidant capacity and the activities of whole blood glutathione peroxidase and erythrocyte superoxide dismutase in 30 healthy client-owned dogs (19 females, 11 males). The effect of age and sex on the measured antioxidant parameters was also investigated. Antioxidant parameters were determined with an automated biochemical analyser, using the commercially available Randox kits. No significant difference in age, weight, and antioxidant parameters was determined between females and males. A significant positive effect of age $(p=0.002$, $\left.\mathrm{r}^{2}=0.284\right)$ on superoxide dismutase activity was confirmed. There was no effect of sex on any of the antioxidant parameters measured. However, we observed a tendency of the effect of sex $\left(p=0.063, r^{2}=0.118\right)$, as well as age $\left(p=0.073, r^{2}=0.111\right)$, on the activity of glutathione peroxidase. Our results are in part comparable with the results of other studies in which the same types of methods and samples were used to determine antioxidant parameters. In conclusion, the sex and age of dogs should be taken into consideration when planning a study on antioxidant status parameters.
\end{abstract}

Key words: antioxidant enzymes, automated assays, canine, oxidative stress, total antioxidant status

\section{INTRODUCTION}

Increasing evidence indicates that oxidative stress significantly impairs the function of organs and plays a major role in the aetiology and pathogenesis of several diseases in humans and animals [1,2]. Total antioxidant capacity (TAC) and antioxidant enzymes, glutathione peroxidase (GSH-Px) and superoxide dismutase (SOD), are commonly used markers of antioxidant status and thus oxidative stress [1,3,4]. TAC represents

*Corresponding author: e-mail: alenka.nemecsvete@vf.uni-lj.si 
the overall antioxidant status of plasma and body fluids. The capacity of known and unknown antioxidants and their synergistic interaction is assessed, thus providing insight into the delicate balance between oxidants and antioxidants in vivo [3,5]. Measuring TAC may help in the assessment of the physiological, environmental, and nutritional factors of the redox status [3]. By removing reactive oxygen species (ROS), intracellular antioxidant enzymes, SOD, GSH-Px, and catalase represent a primary antioxidant defense [6]. Data on the reference ranges of TAC [7], GSH-Px, and SOD [8] in healthy dogs are lacking, and there are no published accepted standard reference methods for their determination. Various measurement methods have been developed for the determination of TAC, GSH-Px and SOD; however, these methods differ greatly among studies, which led to discrepancies in the results [5,9-18].

The correlation between the concentration of antioxidant parameters (TAC, SOD, GSH-Px) and oxidative damage during aging, as well as the sex-related differences of these parameters, have been reported in humans [19-21] but not in dogs.

The aim of this study was to determine the values of plasma TAC and activities of whole blood GSH-Px and erythrocyte SOD in clinically healthy dogs using commercially available kits applied to an automated biochemical analyser. The use of commercially available reagent kits that can be applied to a routine automated biochemical analyser enables the determination of TAC, SOD, and GSH-Px to be more accessible and cheaper due to its operational simplicity and because there is no need for special and expensive equipment and/or chemicals and (in particular) trained personnel to achieve accurate, reproducible and comparable results. Additionally, the effect of age and sex on measured antioxidant parameters was investigated. As ROS have been proposed as important causative agents of aging [20,22,23], one might expect that the antioxidant system of the body is altered. Therefore, we hypothesized that TAC, SOD and GSHPx levels decrease with age. According to the reports that oestrogens are antioxidants themselves [21,24], we hypothesized that female dogs have higher TAC, SOD, and GSH-Px levels in comparison to male dogs.

\section{MATERIALS AND METHODS}

\section{Dogs}

A total of 30 client-owned dogs (19 females and 11 males), aged from 7 to 138 months and body weight from 4.5 to $53.0 \mathrm{~kg}$ scheduled for elective ovariectomy or orchiectomy were recruited for this study (Table 1, Table 2). Age and weight were equally distributed between females and males (Table 2). Only dogs considered healthy on the basis of history, physical examination and results of haematological and serum biochemical analysis (data not shown), were enrolled in the study. The history of the dogs was assessed by means of a questionnaire. Only dogs with no signs of disease that received no therapy, vaccination or supplementation with vitamins and/or antioxidants within the past month were included in the study. Dogs were fed a high-quality commercial 
diet, and only dogs with a body condition score of 4 or 5 according to the World Small Animal Association Body Condition Score [25] were included in this study. The phase of reproductive status of female dogs was assessed only clinically and, according to the owners, they were either in diestrus or anestrus. A written owner consent was obtained before the dogs entered the study. All procedures were approved by the National Ethics Committee and complied with the Slovenian governmental regulations (Animal Protection Act UL RS, 43/2007).

Table 1. Dogs recruited for the study

\begin{tabular}{|c|c|c|c|c|}
\hline Dog No & Breed & Sex & Age (months) & Bodyweight (kg) \\
\hline 1 & $\mathrm{~EB}$ & $\mathrm{M}$ & 34 & 49.1 \\
\hline 2 & GSHP & F & 57 & 25 \\
\hline 3 & $\mathrm{X}$ & M & 114 & 37.5 \\
\hline 4 & $\mathrm{BC}$ & M & 10 & 19 \\
\hline 5 & $\mathrm{X}$ & $\mathrm{F}$ & 12 & 33 \\
\hline 6 & $\mathrm{X}$ & F & 12 & 18 \\
\hline 7 & $\mathrm{X}$ & $\mathrm{F}$ & 72 & 35 \\
\hline 8 & $\mathrm{X}$ & F & 24 & 32 \\
\hline 9 & IWH & $\mathrm{F}$ & 31 & 53 \\
\hline 10 & GB & F & 16 & 22 \\
\hline 11 & AST & $\mathrm{F}$ & 102 & 32.1 \\
\hline 12 & AST & M & 120 & 29.05 \\
\hline 13 & $\mathrm{TP}$ & $\mathrm{F}$ & 50 & 4.5 \\
\hline 14 & MS & F & 14 & 9.5 \\
\hline 15 & LR & $\mathrm{F}$ & 9 & 24.3 \\
\hline 16 & $\mathrm{X}$ & $\mathrm{F}$ & 25 & 8.46 \\
\hline 17 & $\mathrm{X}$ & $\mathrm{F}$ & 92 & 12.42 \\
\hline 18 & $\mathrm{~EB}$ & F & 69 & 19.6 \\
\hline 19 & BSM & M & 96 & 33 \\
\hline 20 & BSM & F & 138 & 22 \\
\hline 21 & BSM & M & 24 & 32 \\
\hline 22 & GB & F & 42 & 31.2 \\
\hline 23 & $\mathrm{X}$ & $\mathrm{F}$ & 48 & 28.7 \\
\hline 24 & B & $\mathrm{M}$ & 60 & 48.6 \\
\hline 25 & $\mathrm{X}$ & M & 9 & 18.8 \\
\hline 26 & $\mathrm{TT}$ & $\mathrm{M}$ & 13 & 8.4 \\
\hline 27 & $\mathrm{GH}$ & M & 94 & 37.35 \\
\hline 28 & BG & $\mathrm{F}$ & 7 & 11.1 \\
\hline 29 & $\mathrm{X}$ & F & 8 & 33 \\
\hline 30 & WHWT & $\mathrm{M}$ & 126 & 11 \\
\hline
\end{tabular}

EB - English Bulldog, GSHP - German Shorthaired Pointer, X - mongrel, BC - Border Collie, IWH - Irish Wolfhound, GB- German Boxer, AST - American Stafford Terrier, TP - Toy Poodle, MS - Miniature Schnauzer, LR - Labrador Retriever, BSM - Belgian Shepherd Malinois, B - Beauceron, TT - Tibetan Terrier, GH - Greyhound, BG - Beagle, WHWT West Highland White Terrier, M - male, F - female, No - number 
Table 2. Age and weight (medians, minimum and maximum values, means and standard deviations) of female (19), male (11) and all (30) healthy dogs

\begin{tabular}{lcccc}
\hline & Median & Min & Max & Mean \pm SD \\
\hline Age (months) & & & & \\
Females & 31 & 9 & 138 & $43.6 \pm 37.0$ \\
Males & 60 & 7 & 126 & $63.6 \pm 47.4$ \\
All dogs & 38 & & & $50.9 \pm 41.5$ \\
Weight (kg) & & 4.5 & 53.0 & \\
Females & 24.3 & 8.4 & 49.1 & $24.0 \pm 11.8$ \\
Males & 32.0 & 4.5 & 53.0 & $26.0 \pm 13.8$ \\
All dogs & 26.9 & & & \\
\hline
\end{tabular}

Min - minimum value, Max - maximum value, $\mathrm{SD}$ - standard deviation

\section{Blood samples collection and analyses}

Venous blood samples for the determination of plasma TAC, GSH-Px activity in whole blood and SOD activity in erythrocyte lysate were collected from 8 a.m. to 9 a.m. from fasted animals in Vacutainer tubes containing lithium heparin (Becton Dickinson, Franklin Lakes, New Jersey, USA). The dogs were fasted at least 12 hours before blood sampling. Cephalic venepuncture was performed with a 20 -gauge needle, and $10 \mathrm{~mL}$ of blood were collected. Blood samples for the determination of TAC levels were immediately centrifuged at $1500 \times \mathrm{g}$ for 15 minutes at $4{ }^{\circ} \mathrm{C}$. Plasma was separated and immediately frozen at $-80{ }^{\circ} \mathrm{C}$ until analysis. Aliquots of heparinised whole blood for the determination of GSH-Px activity were prepared and immediately frozen at $-80{ }^{\circ} \mathrm{C}$ until analysis. Haemolysed red blood cells for the determination of SOD activity were prepared immediately after blood collection, following the manufacturer's (Ransod kit, Randox, Crumlin, UK) instructions, and stored at -80 ${ }^{\circ} \mathrm{C}$ until analysis. Haemoglobin concentration in red blood cell haemolysates was determined with a cyano-methaemoglobin method using an automated biochemical analyser RX-Daytona (Randox, Crumlin, UK). Plasma levels of TAC and activities of GSH-Px and SOD were determined with an RX-Daytona automated biochemical analyser (Randox, Crumlin, UK), using the commercially available TAS (Total Antioxidant Status), Ransel and Ransod kits (all Randox, Crumlin, UK). The volumes of the samples needed for TAC, GSH-Px and SOD determinations on the RXDaytona biochemical analyser were $100 \mu \mathrm{L}$ of heparin plasma, $25 \mu \mathrm{L}$ of whole blood and $30 \mu \mathrm{L}$ of haemolysate, respectively. The TAS kit is based on the method of Miller et al. [16]), which is one of the TEAC (trolox equivalent antioxidant capacity) ABTS (2,2'-azino-bis (3-ethylbenzothiazoline-6-sulphonic acid)) based methods and has been previously used in dogs [18]. The results are expressed as mmol/L of Trolox (6-hydroxy-2,5,7,8-tetramethylchroman-2-carboxylic acid) equivalents. The Ransel kit is based on the method of Paglia and Valentine [9] and has been previously used in dogs [26-28]. The Ransod kit is based on the method of McCord and Fridovich [10] and has been previously used in dogs [26,27]. Activities of GSH-Px and SOD were expressed as units per gram of haemoglobin $(\mathrm{U} / \mathrm{g} \mathrm{Hgb})$. All analyses were performed 
in duplicate. For all antioxidant parameters, identical samples (control material from Randox (TAS, Ransel, and Ransod controls) and samples from one of the dogs) were repeatedly analysed to determine within-run and between-run coefficients of variation $(\mathrm{CVs})$.

\section{Statistical analysis}

Data were analysed with commercial software (SPSS 22.0, Chicago, Illinois, USA). Descriptive statistics was used to describe the basic features of the data. The ShapiroWilk test was performed for the evaluation of normality. According to the results of the normality tests, a Mann-Whitney $U$ test was performed to test for statistically significant differences in age and TAC and independent sample t-test for statistically significant differences in weight, SOD and GSH-Px between female and male dogs. Linear regression analysis was used to investigate the effect of age and sex on the antioxidant parameters measured. A p-value of $<0.05$ was considered statistically significant.

\section{RESULTS}

Normal distribution was shown for SOD activity, but not for TAC and GSH-Px. Linear regression analysis showed a significant effect of age on SOD activity ( $\mathrm{p}=$ 0.002, $\mathrm{r}^{2}=$ 0.284; Fig. 1), but not on TAC level (Fig. 2) and activity of GSH-Px (Fig. 3). There was no effect of sex on any of the antioxidant parameters measured. However, there was a tendency for an effect of $\operatorname{sex}\left(\mathrm{p}=0.063, \mathrm{r}^{2}=0.118\right)$, as well as age $(\mathrm{p}=$

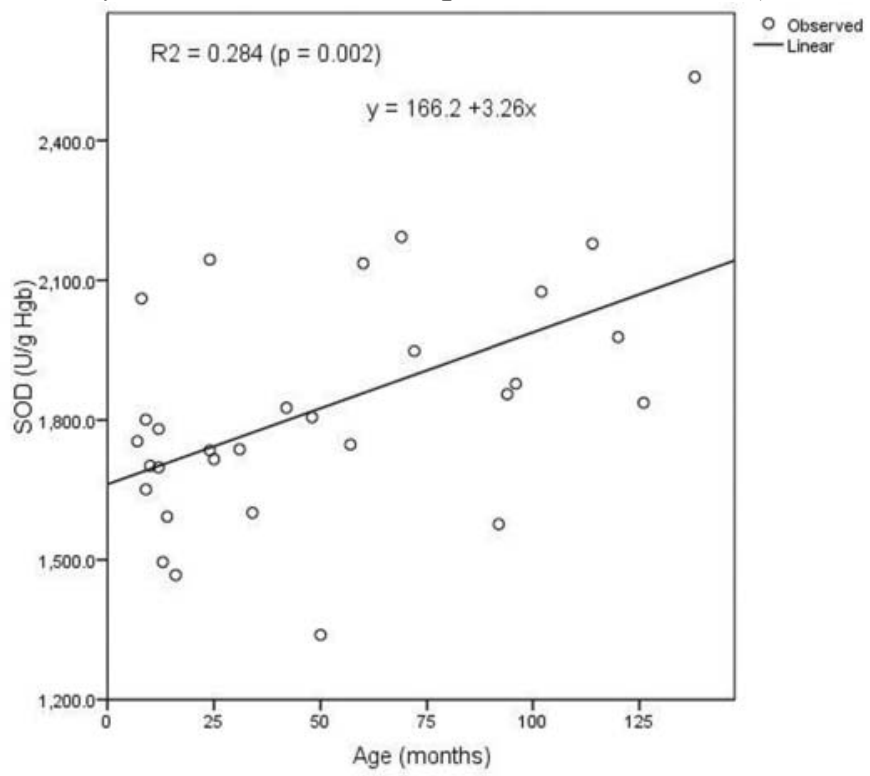

Figure 1. Association of superoxide dismutase (SOD) activity with age (linear regression analysis) 
$\left.0.073, \mathrm{r}^{2}=0.111\right)$, on activity of GSH-Px. Results of the analysed parameters are presented in Table 3 (females, males, all $30 \mathrm{dogs}$ ) and the coefficients of variation in Table 4. There were no significant differences in age and weight and any of the antioxidant parameters between female and male dogs (Table 2, Table 3).

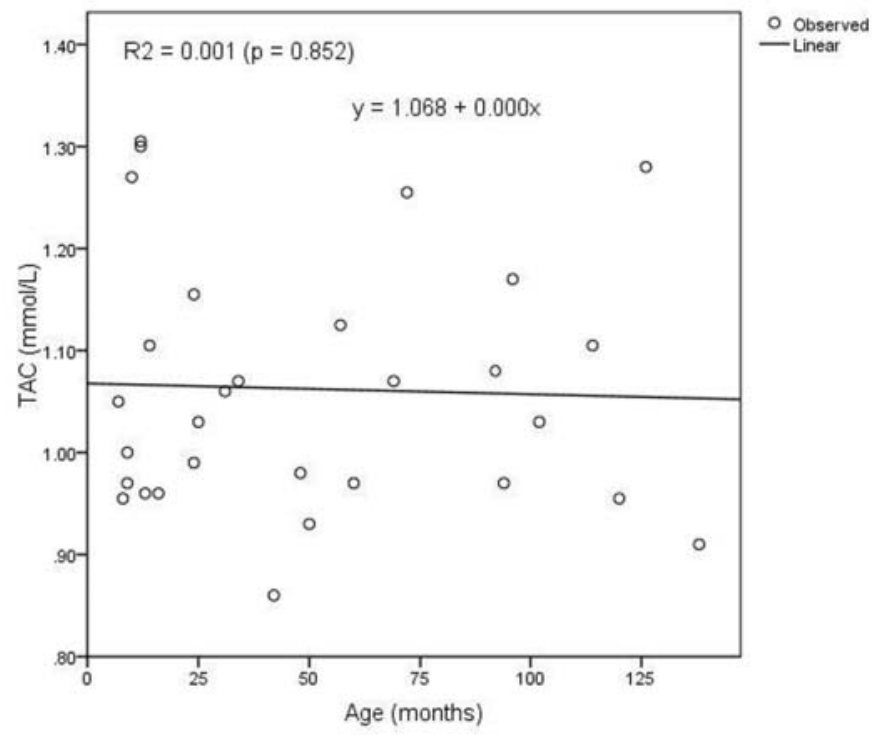

Figure 2. Association of total antioxidant capacity (TAC) level with age (linear regression analysis)

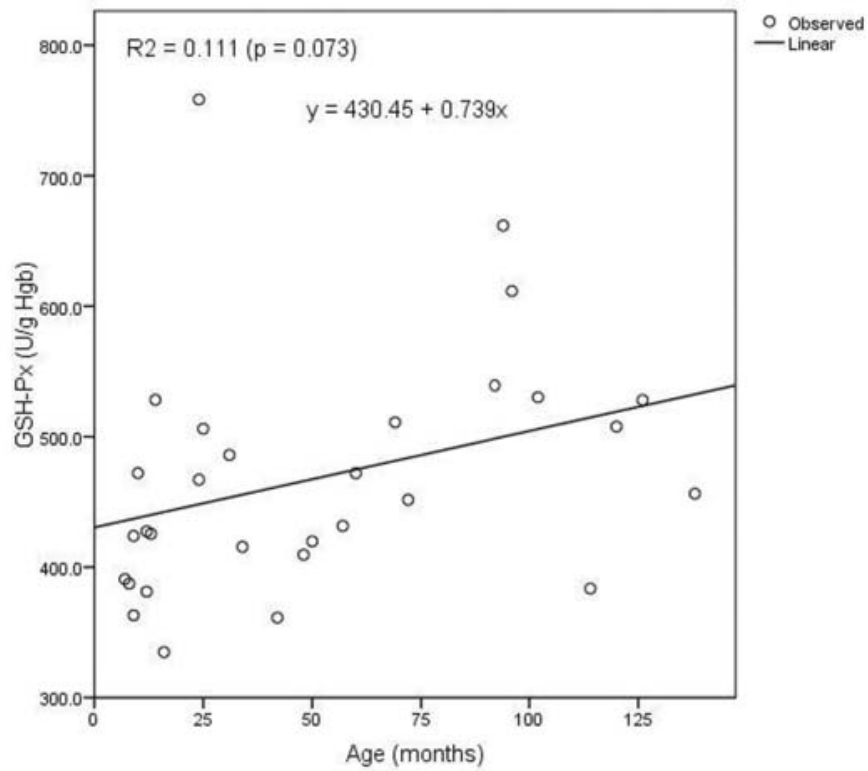

Figure 3. Association of glutathione peroxidase (GSH-Px) activity with age (linear regression analysis) 
Table 3. Medians, percentile ranges (males, females: 10-90\%; all dogs: 5-95\%), 90\% confidence intervals, minimum and maximum values, means and standard deviations of antioxidant parameters in female (19), male (11) and all (30) healthy dogs

\begin{tabular}{|c|c|c|c|c|c|c|}
\hline & Median & $\begin{array}{l}\text { Percentile } \\
\text { range }\end{array}$ & $90 \% \mathrm{CI}$ & Min & Max & Mean \pm SD \\
\hline \multicolumn{7}{|c|}{ TAC (mmol/L) } \\
\hline Females & 1.05 & $0.91-1.30$ & $1.01-1.11$ & 0.86 & 1.31 & $1.06 \pm 0.13$ \\
\hline Males & 1.00 & $0.96-1.28$ & $1.00-1.13$ & 1.00 & 1.28 & $1.07 \pm 0.12$ \\
\hline All dogs & 1.04 & $0.89-1.30$ & $1.02-1.10$ & 0.86 & 1.31 & $1.06 \pm 0.12$ \\
\hline \multicolumn{7}{|c|}{ SOD (U/g Hgb) } \\
\hline Females & 1754.4 & 1467.2-2193.0 & 1702.7-1917.3 & 1338.6 & 2536.1 & $1810.0 \pm 269.6$ \\
\hline Males & 1855.5 & 1516.4-2171.7 & 1732.5-1986.9 & 1495.3 & 2178.6 & $1859.7 \pm 232.8$ \\
\hline All dogs & 1790.8 & $1409.3-2347.4$ & 1749.5-1907.0 & 1338.6 & 2536.1 & $1828.2 \pm 253.8$ \\
\hline \multicolumn{7}{|c|}{ GSH-Px (U/g Hgb) } \\
\hline Females & 431.6 & $361.3-530.2$ & $420.3-468.5$ & 334.9 & 539.3 & $441.4 \pm 60.5$ \\
\hline Males & 472.1 & $367.2-739.1$ & $441.7-576.4$ & 363.1 & 758.5 & $509.0 \pm 123.3$ \\
\hline All dogs & 454.0 & $349.4-705.3$ & $439.5-496.7$ & 334.9 & 758.5 & $468.1 \pm 91.3$ \\
\hline
\end{tabular}

TAC - total antioxidant capacity, SOD - superoxide dismutase, GSH-Px - glutathione peroxidase, $\mathrm{U} / \mathrm{g} \mathrm{Hgb}$ - units per gram of haemoglobin, $90 \% \mathrm{CI}-90 \%$ confidence interval, Min - minimum value, Max - maximum value, $\mathrm{SD}$ - standard deviation

Table 4. Coefficients of variation (CVs) for antioxidant parameters in healthy dogs

\begin{tabular}{lcccccc}
\hline & \multicolumn{2}{c}{ TAC $(\mathrm{mmol} / \mathrm{L})$} & \multicolumn{2}{c}{ SOD $(\mathrm{U} / \mathrm{mL})$} & \multicolumn{2}{c}{ GSH-Px $(\mathrm{U} / \mathrm{L})$} \\
\cline { 2 - 7 } & $\begin{array}{c}\text { TAS } \\
\text { control }\end{array}$ & $\begin{array}{c}\text { Canine } \\
\text { sample }\end{array}$ & $\begin{array}{c}\text { Ransod } \\
\text { control }\end{array}$ & $\begin{array}{c}\text { Canine } \\
\text { sample }\end{array}$ & $\begin{array}{c}\text { Ransod } \\
\text { control }\end{array}$ & $\begin{array}{c}\text { Canine } \\
\text { sample }\end{array}$ \\
\hline within-run & & & & & & \\
$\mathrm{n}$ & 6 & 6 & 20 & 20 & 20 & 20 \\
$\mathrm{CV}(\%)$ & 1.25 & 1.13 & 4.66 & 3.33 & 1.67 & 2.09 \\
between-run & & & & & & \\
$\mathrm{n}$ & 6 & 6 & 6 & 6 & 6 & 6 \\
$\mathrm{CV}(\%)$ & 4.33 & 2.22 & 2.37 & 1.66 & 3.95 & 1.60 \\
\hline
\end{tabular}

TAC - total antioxidant capacity, TAS - total antioxidants status, SOD - superoxide dismutase, GSH-Px - glutathione peroxidase, CV - coefficient of variation, $\%$ - percentage, $\mathrm{n}$ - number of samples analysed.

\section{DISCUSSION}

This study provides information on the values of TAC, GSH-Px, and SOD determined in healthy dogs, using commercially available kits applied to an automated biochemical analyser. The advantages of using automated assays include reduced analytical variations, considerable reductions in time and smaller sample volumes, in comparison to manual assays [15,29-32]. Our results were compared mainly to the results of the studies in which small groups of healthy dogs served as control groups.

Several methods have been developed to measure the TAC of different biological samples. The methods vary widely, which can result in non-comparable results among 
studies $[5,18,33]$. In the present study, plasma TAC values were determined by using the TEAC ABTS-based method. The TEAC method is one of the most commonly used colorimetric methods; it was first reported by Miller et al. [16] and later commercialised by Randox Laboratories as the TAS kit [5], also used in our research. Although this assay has certain shortcomings [34,35], it is often used in research and routine clinical biochemistry laboratories due to its operational simplicity and ability to simultaneously determine hydrophilic and lipophilic antioxidants [16,18]. There are many different versions of TEAC assay with the improved method developed by Erel [32], which is recently the most commonly used method in dogs [18]. The method of Erel [32] significantly correlates with the Randox TAS assay. Most of the methods developed for TAC measurements in humans are used for the measurement of TAC values in canine samples [18]. However, Rubio et al. [36] recently published the results of full validation of an automated assay for the measurement of cupric reducing antioxidant capacity in the serum of dogs. Our results on TAC are in good agreement with the results of studies that employed the same or similar assay kit for the assessment of plasma or serum TAC in healthy dogs [7, 26,37,38].

In comparison to our results, much lower TAC values were obtained in healthy dogs in the studies $[39,40]$ that employed the novel TEAC ABTS-method developed by Erel [32]. The difference may be attributed to the difference in sample type, plasma (used in our study) and serum (used by Kocaturk et al. [39] and Rudoler et al. [40]). The difference between plasma and serum TAC values may originate from fibrinogen, present in the plasma, and having an antioxidant activity [32]. Hetyey et al. [38] determined TAC values in healthy dogs and in dogs with heart disease with two different methods: FRAP (Ferric Reducing Ability of Plasma) and TEAC. In the control dogs, TEAC values were higher than FRAP values, which was attributed to methodological reasons and to the different reactivity of the two assays to the various antioxidants. In addition, FRAP values were significantly higher in patients with heart disease than in controls, but not TAS values, indicating that at least two methods should be used for the measurement of TAC [38]. Interestingly, FRAP values determined in army service patrol dogs [41] were in good agreement with TAC values determined in our study. As expected, our TAC results were not in accordance with the TAC values determined in dogs with ORAC (Oxygen Radical Absorbance Capacity) [42,43] or TRAP (Total Radical-Trapping Antioxidant Parameter) [44,45] methods due to the great difference in methodological principals.

The correlation between antioxidant capacity and oxidative damage during aging, as well as sex-related differences in TAC values, has been reported in humans $[19,20,46]$ but not in dogs. Our results showed no effect of age or sex on TAC values in healthy dogs. There was also no significant difference in TAC values between male and female dogs. Most of the studies in healthy humans showed a significant decline of TAC levels with age [20,46-48]. Moreover, significantly lower TAC values were found in older men than in young men, but no such difference was found in women [46-48]. 
As with TAC, several methods have been developed for the determination of SOD $[10,11,13,17]$ and GSH-Px $[9,12,14]$ activities in blood samples. Spectrophotometric methods are among the most widely used.

Analytical methods for the determination of SOD activity are based on the ability of SOD to catalyse the superoxide radical dismutation to $\mathrm{H}_{2} \mathrm{O}_{2}$. All these methods are indirect and require a source and a system for detection of the superoxide radical $[11,17]$. The use of different combinations of superoxide radical generators and detectors may result in non-comparable results among studies. Our results on SOD are in agreement with the results of the study by Plevnik Kapun et al. [26] in which the same assay kit and sample type were used. Surprisingly, our results differ greatly from the results of Britti et al. [49], although the same assay kit and sample type were used in both studies. The difference might be due to different biochemical analysers being used, as well as due to differences in pre-analytical considerations and the dogs included in the study. In contrast, our results are in general agreement with the results of studies in which other methods were used [50-52].

There is evidence that the activities of antioxidant enzymes are under the control of steroid hormones, which can explain not only sex-dependent but also age-dependent changes. Moreover, oestrogens are antioxidants themselves, which can also be the reason for these differences [21]. However, human studies revealed controversial findings regarding sex-related differences in the activity of SOD determined in the blood samples of healthy subjects $[21,47,53,54]$. Our study showed no effect of sex on SOD activity in healthy dogs and no significant difference in SOD activity between male and female dogs was observed. Similarly, Todorova et al. [8] reported no sexrelated differences in SOD activity in healthy dogs. Vajdovich et al. [55] reported no significant differences in SOD activity between young male and female dogs, but their study showed significantly higher SOD activity in old female dogs in comparison to old males.

In the majority of studies, an age-related decrease in SOD activity in human erythrocytes seems to be a rather constant finding $[22,31,53,54]$, though some researchers could not detect any significant age-related difference in SOD activity $[47,48]$, or they reported an age-related increase in erythrocyte SOD activity [23]. Our study demonstrated a significant (linear) positive effect of age on SOD activity in healthy dogs. Vajdovich et al. [55] reported a significantly higher erythrocyte SOD activity in old dogs than in young ones. The increased activity of this antioxidant enzyme in older animals seems to be a compensatory mechanism for high levels of ROS at an older age.

The most widely accepted assay for the determination of GSH-Px activity is the method of Paglia and Valentine [9], in which the oxidation of glutathione (GSH) is coupled to NADPH oxidation by glutathione reductase. Many modifications of the coupled assay have been published, and they vary in substrate concentrations, type of peroxide, presence of chelators and inhibitors, $\mathrm{pH}$, and temperature [15]. The results of our study are in general agreement with the results of studies carried out by Plevnik 
Kapun et al. [26], Winter et al. [43] and Stowe et al. [44], but are not comparable to others $[37,51,52]$. In all these studies, the activity of GSH-Px was determined in whole blood using assays based on the method of Paglia and Valentine [9]. Differences in GSH-Px levels may be ascribed to differences in pre-analytical considerations, specific assay conditions regarding the concentration of reagents, and dogs included in these studies.

Our study demonstrated no significant difference in GSH-Px activity between male and female dogs and no effect of sex on GSH-Px activity, although the activities of GSH-Px tended to be higher $(p=0.063)$ in male than in female dogs. In contrast, Vajdovich et al. [55] demonstrated significantly higher GSH-Px activity in old female dogs in comparison to male dogs, but there was no difference between young male and female dogs. The majority of studies in humans [22,23,47,48.53] revealed no sexrelated differences in the activity of GSH-Px activity in healthy subjects.

Stowe et al. [44] reported a significant increase of whole blood GSH-Px with aging in Labrador retrievers. In contrast, our study showed no effect of age on GSH-Px activity, but the activities of GSH-Px tended to be higher in old dogs than in the young ones ( $p=0.073)$. Similarly, Vajdovich et al. [55] reported significantly higher GSHPx activity in old male dogs than in young ones of either sex. While some studies in humans reported that the activity of GSH-Px increases with age [22,48,54], others found an age-related decrease in activity of this antioxidant enzyme $[47,56]$ or no agerelated changes $[23,31]$.

\section{CONCLUSIONS}

The present study provides information on the ranges of TAC, GSH-Px, and SOD determined in healthy dogs, using commercially available kits applied to an automated biochemical analyser. The advantages of using automated assays are reduced analytical variation, considerable reductions in time, and smaller sample volumes, in comparison to manual assays, and can be routinely used to evaluate the oxidative stress in a group of healthy dogs, serving as a control group, and groups of dogs with various pathological conditions, especially when monitoring the effects of the disease and/or treatment in a patient. Furthermore, sex and age should be taken into consideration when planning a study on antioxidant parameters in dogs.

Our results warrant further studies in large groups of healthy dogs in order to determine the reference values of antioxidant parameters using the methods that were employed in this study.

\section{Acknowledgements}

The authors acknowledge the financial support of the Slovenian Research Agency (research programme P4-0053). 


\section{Authors' contributions}

KT and ANS contributed to conception and design of the study. KT drafted the manuscript, as well as performed all the necessary collection and preparation of blood samples and help evaluating dogs included in the study. ANS performed all the analyses (hematological an biochemical analyses, determination of total antioxidant capacity and activities of glutathione peroxidase and superoxide dismutase), contributed to the statistical analyses and interpretation of data, help drafting the manuscript, critically revised the manuscript and agree to be accountable for all aspects of the work in ensuring that questions relating to the accuracy or integrity of any part of the of work are appropriately investigated and resolved. AS and BL participated in collection of blood samples, participated in study design, its coordination, as well as critically revised the manuscript. All authors read and approved the final manuscript.

\section{Declaration of conflicting interests}

The author(s) declared no potential conflicts of interest with respect to the research, authorship, and/or publication of this article.

\section{REFERENCES}

1. McMichael MA: Oxidative stress, antioxidants, and assessment of oxidative stress in dogs and cats. J Am Vet Med Assoc 2007, 231:714-720.

2. Valko M, Leibfritz D, Moncol J, Cronin MTD, Mazur M, Telser J: Free radicals and antioxidants in normal physiological functions and human disease. Int J Biochem Cell Biol 2007, 39:44-84.

3. Ghiselli A, Serafini M, Natella F, Scaccini C: Total antioxidant capacity as a tool to assess redox status: critical view and experimental data. Free Radic Biol Med 2000, 29:1106-1114.

4. Dotan Y, Lichtenberg D, Pinchuk I: Lipid peroxidation cannot be used as a universal criterion of oxidative stress. Prog Lipid Res 2004, 43:200-227.

5. Prior RL, Cao G: In vivo total antioxidant capacity: comparison of different analytical methods. Free Radic Biol Med 1999, 27:1173-1181.

6. Mates JM. Effect of antioxidant enzymes in the molecular control of reactive oxygen species. Toxicology 2000,153:83-104.

7. Nemec A, Drobnič-Košorok M, Skitek M, Pavlica Z, Galac S, Butinar J: Total Antioxidant Capacity (TAC) Values and Their Correlation with Individual Antioxidants in Healthy Beagles. Acta Vet Brno 2000, 69:297-303.

8. Todorova I, Simeonova G, Kyuchukova D, Dinev D, Gadjeva V: Reference values of oxidative stress parameters (MDA, SOD, CAT) in dogs and cats. Comp Clin Path 2005, 13:190-194.

9. Paglia DE, Valentine WN: Studies on the quantitative and qualitative characterization of erythrocyte glutathione peroxidase. J Lab Clin Med 1967, 70:158-169. 
10. McCord JM, Fridovich I: Superoxide dismutase. An enzymic function for erythrocuprein (hemocuprein). J Biol Chem 1969, 244:6049-6055.

11. Flohe L, Otting F: Superoxide dismutase assays. Methods Enzymol 1984, 105:93-104.

12. Flohe L, Gunzler WA: Assays of glutathione peroxidase. Methods Enzymol 1984, 105:114 121.

13. Oyanagui Y: Reevaluation of assay methods and establishment of kit for superoxide dismutase activity. Anal Biochem 1984, 142:290-296.

14. Faraji B, Kang HK, Valentine JL: Methods compared for determining glutathione peroxidase activity in blood. Clin Chem 1987, 33:539-543.

15. Hawkes WC, Craig KA: Automated continuous-flow colorimetric determination of glutathione peroxidase with dichloroindophenol. Anal Biochem 1990, 186:46-52.

16. Miller NJ, Rice-Evans C, Davies MJ, Gopinathan V, Milner A: A novel method for measuring antioxidant capacity and its application to monitoring the antioxidant status in premature neonates. Clin Sci (Lond) 1993, 84:407-412.

17. Girotti S, Fini F, Ferri E, Budini R, Piazzi S, Cantagalli D: Determination of superoxide dismutase in erythrocytes by a chemiluminescent assay. Talanta 2000, 51:685-692.

18. Rubio CP, Hernández-Ruiz J, Martinez-Subiela S, Tvarijonaviciute A, Ceron JJ. Spectrophotometric assays for total antioxidant capacity (TAC) in dog serum: an update. BMC Vet Res 2016:12(1):166, DOI . 10.1186/s12917-016-0792-7.

19. Aejmelaeus RT, Holm P, Kaukinen U, Metsa-Ketela TJ, Laippala P, Hervonen AL, Alho HE: Age-related changes in the peroxyl radical scavenging capacity of human plasma. Free Radic Biol Med 1997, 23:69-75.

20. Pandey KB, Rizvi SI: Markers of oxidative stress in erythrocytes and plasma during aging in humans. Oxid Med Cell Longev 2010, 3:2-12.

21. Giergiel M, Lopucki M, Stachowicz N, Kankofer M: The influence of age and gender on antioxidant enzyme activities in humans and laboratory animals. Aging Clin Exp Res 2012, 24:561-569.

22. Inal ME, Kanbak G, Sunal E: Antioxidant enzyme activities and malondialdehyde levels related to aging. Clin Chim Acta 2001, 305:75-80.

23. Kasapoglu M, Ozben T: Alterations of antioxidant enzymes and oxidative stress markers in aging. Exp Gerontol 2001, 36:209-220.

24. Niki E, Nakano M. Estrogens as antioxidants. Methods Enzymol. 1990,186:330-3.

25. Freeman L, Becvarova I, Cave N, MacKay C, Nguyen P, Rama B, Takashima G, Tiffin R, van Beukelen P, Yathiraj S; WSAVA Nutritional Assessment Guidelines Task Force. WSAVA Nutritional Assessment Guidelines. Compend Contin Educ Vet 2011, 33(8):E1-9.

26. Kapun AP, Salobir J, Levart A, Kotnik T, Svete AN: Oxidative stress markers in canine atopic dermatitis. Res Vet Sci 2012, 92:469-470.

27. Nikahval B, Hosseini Z, Nazifi S, Foroud M. Evaluation of antioxidant enzymes changes in synovial fluid and blood, following experimental osteoarthritis in dogs. Comp Clin Path 2015, 24:23-27.

28. van Zelst M, Hesta M, Gray K, staunton R, Du Laing G, Janssens GPJ. Biomarkers of selenium status in dogs. BMC Vet Res 2016, 12:15. DOI 10.1186/s12917-016-0639-2

29. L'Abbe MR, Fischer PW: An automated method for the determination of Cu,Zn-superoxide dismutase in plasma and erythrocytes using an ABA-200 discrete analyzer. Clin Biochem 1986, 19:175-178. 
30. Wheeler CR, Salzman JA, Elsayed NM, Omaye ST, Korte DWJ: Automated assays for superoxide dismutase, catalase, glutathione peroxidase, and glutathione reductase activity. Anal Biochem 1990, 184:193-199.

31. Andersen HR, Nielsen JB, Nielsen F, Grandjean P: Antioxidative enzyme activities in human erythrocytes. Clin Chem 1997, 43:562-568.

32. Erel O: A novel automated direct measurement method for total antioxidant capacity using a new generation, more stable ABTS radical cation. Clin Biochem 2004, 37:277-285.

33. Huang D, Ou B, Prior RL: The chemistry behind antioxidant capacity assays. J Agric Food Chem 2005, 53:1841-1856.

34. Schofield D, Braganza JM. Shortcomings of an automated assay for total antioxidant status in biological fluids. Clin Chem. 1996, 42:1712-4.

35. Strube M, Haenen GR, Van Den Berg H, Bast A. Pitfalls in a method for assessment of total antioxidant capacity. Free Radic Res. 1997, 26:515-21.

36. Rubio CP, Tvarijonaviciute A, Martinez-Subiela S, Hernández-Ruiz J, Cerón JJ. Validation of an automated assay for the measurement of cupric reducing antioxidant capacity in serum of dogs. BMC Vet Res 2016, 12:137. DOI: 10.1186/s12917-016-0760-2.

37. Hinchcliff KW, Reinhart GA, DiSilvestro R, Reynolds A, Blostein-Fujii A, Swenson RA: Oxidant stress in sled dogs subjected to repetitive endurance exercise. Am J Vet Res 2000, 61:512-517.

38. Hetyey CS, Manczur F, Dudas-Gyorki Z, Reiczigel J, Ribiczey P, Vajdovich P, Voros K. Plasma antioxidant capacity in dogs with naturally occurring heart diseases. J Vet Med A Physiol Pathol Clin Med 2007, 54:36-39.

39. Kocaturk M, Tvarijonaviciute A, Martinez-Subiela S, Tecles F, Eralp O, Yilmaz Z, Ceron JJ. Inflammatory and oxidative biomarkers of disease severity in dogs with parvoviral enteritis. J Small Anim Pract 2015, 56:119-24. DOI: 10.1111/jsap.12250. Epub 2014 Jul 10.

40. Rudoler N, Harrus S, Martinez-Subiela S, Tvarijonaviciute A, van Straten M, Cerón JJ, Baneth G. Comparison of the acute phase protein and antioxidant responses in dogs vaccinated against canine monocytic ehrlichiosis and naive-challenged dogs. Parasit Vectors 2015, 8:175. DOI: 10.1186/s13071-015-0798-1.

41. Kukovska V, Celeska I, Ruškovska T, Valčić O. Effects of rose hip and grapeseed dietary supplementation on serum oxidative stress parameters in dogs before and after physical exercise. Acta Vet Beograd 2015, 65:404-416.

42. Freeman LM, Rush JE, Milbury PE, Blumberg JB: Antioxidant status and biomarkers of oxidative stress in dogs with congestive heart failure. J Vet Intern Med 2005, 19:537-541.

43. Winter JL, Barber LG, Freeman L, Griessmayr PC, Milbury PE, Blumberg JB: Antioxidant status and biomarkers of oxidative stress in dogs with lymphoma. J Vet Intern Med 2009, 23:311-316.

44. Stowe HD, Lawler DF, Kealy RD: Antioxidant status of pair-fed labrador retrievers is affected by diet restriction and aging. J Nutr 2006, 136:1844-1848.

45. Uhrikova I, Rehakova K, Rauserova-Lexmaulova L, Lojek A DJ: Total antioxidant capacity in dogs with gastric dilatation and volvulus. Vet Med (Praha) 2012, 4:207 - 211.

46. Wang XL, Rainwater DL, VandeBerg JF, Mitchell BD, Mahaney MC: Genetic contributions to plasma total antioxidant activity. Arterioscler Thromb Vasc Biol 2001, 21:1190-1195.

47. Mendoza-Nunez VM, Ruiz-Ramos M, Sanchez-Rodriguez MA, Retana-Ugalde R, MunozSanchez JL: Aging-related oxidative stress in healthy humans. Tohoku J Exp Med 2007, 213:261-268. 
48. Hübner-Woźniak E, Okecka-Szymańska J, Stupnicki R, Malara M, Kozdroń E: Age-Related Blood Antioxidant Capacity in Men and Women. J Med Biochem 2011, 30.

49. Britti D, Sconza S, Morittu VM, Santori D, Boari A: Superoxide dismutase and Glutathione peroxidase in the blood of dogs with Leishmaniasis. Vet Res Commun 2008, 32 Suppl 1: S251-S254.

50. Freeman LM, Brown DJ, Rush JE: Assessment of degree of oxidative stress and antioxidant concentrations in dogs with idiopathic dilated cardiomyopathy. J Am Vet Med Assoc 1999, 215:644-646.

51. Szczubial M, Kankofer M, Lopuszynski W, Dabrowski R, Lipko J: Oxidative stress parameters in bitches with mammary gland tumours. J Vet Med A Physiol Pathol Clin Med 2004, 51:336-340.

52. Singh SK, Dimri U, Sharma MC, Swarup D, Sharma B: Determination of oxidative status and apoptosis in peripheral blood of dogs with sarcoptic mange. Vet Parasitol 2011, 178:330-338.

53. Ceballos-Picot I, Trivier JM, Nicole A, Sinet PM, Thevenin M: Age-correlated modifications of copper-zinc superoxide dismutase and glutathione-related enzyme activities in human erythrocytes. Clin Chem 1992, 38:66-70.

54. Bolzan AD, Bianchi MS, Bianchi NO: Superoxide dismutase, catalase and glutathione peroxidase activities in human blood: influence of sex, age and cigarette smoking. Clin Biochem 1997, 30:449-454.

55. Vajdovich P, Gaal T, Szilagyi A, Harnos A: Changes in some red blood cell and clinical laboratory parameters in young and old Beagle dogs. Vet Res Commun 1997, 21:463-470.

56. Guemouri L, Artur Y, Herbeth B, Jeandel C, Cuny G, Siest G: Biological variability of superoxide dismutase, glutathione peroxidase, and catalase in blood. Clin Chem 1991, 37:1932-1937.

\section{UKUPNI ANTIOKSIDATIVNI PLAZMA KAPACITET I AKTIVNOST GLUTATION PEROKSIDAZE I SUPEROKSID DISMUTAZE KRVI ODREĐIVAN U ZDRAVIM PSIMA UPOTREBOM KOMERCIJALNIH DIJAGNOSTIČKIH KOMPLETA}

\section{TOMSIČ Katerina, SELIŠKAR Alenka, LUKANC Barbara, NEMEC SVETE Alenka}

Do danas nedostaju podaci koji se odnose na vrednosti pojedinih antioksidativnih krvnih parametara kod zdravih pasa i to ukupan antioksidativni kapacitet, glutation peroksidaza i superoksid dismutaza. Isto tako, ne postoje objavljene referentne standardne vrednosti i metode za ispitivanje ovih parametara. Cilj studije je bio da se odredi vrednosti ukupnog antioksidativnog kapaciteta kao i aktivnosti glutation peroksidaze $\mathrm{i}$ superoksid dismutaze u punoj krvi 30 zdravih pasa, privatnih vlasnika. Uzorci su uzimani od 19 kuja i 11 muških pasa. Istovremeno, ispitivan je uticaj starosti i pola na pomenute antioksidativne parametre. Antioksidativni parametri su ustanovljeni pomoću 
automatskog analizatora, upotrebom komercijalnih Randox dijagnostičkih kompleta. Nisu uočene značajne razlike između muških i ženskih jedinki u odnosu na starost, telesnu masu i antioksidativne parametre. Potvrđen je značajan pozitivan uticaj uzrasta $(p=0,002, r 2=0,284)$ na superoksid dismutazu. Nije bilo nikakvog uticaja pola pasa na bilo koji antioksidativni parametar koji je ispitivan. Međutim, uočena je tendencija efekta pola $\left(p=0,063, r^{2}=0,118\right)$, kao i uzrasta $\left(p=0,073, r^{2}=0,111\right)$, na aktivnost glutation peroksidaze. Naši rezultati su delimično u skladu sa drugim studijama u kojima je upotrebljen isti metod za iste uzorke, za procenu antioksidativnih parametara. Može se zaključiti da prilikom planiranja ispitivanja parametara antioksidativnog statusa kod pasa, treba uzeti u obzir i faktore kao što su pol i uzrast životinja koje se ispituju. 